\title{
NITRIC OXIDE PRODUCTS ARE NOT ASSOCIATED WITH METABOLIC SYNDROME
}

\author{
PRODUKTI AZOT-MONOKSIDA NISU POVEZANI SA METABOLIČKIM SINDROMOM
}

\author{
Aleksandra Klisic ${ }^{1}$, Gordana Kocic ${ }^{2}$, Nebojsa Kavaric ${ }^{1}$, Radmila Pavlovic ${ }^{3}$, Ivan Soldatovic ${ }^{4}$, Ana Ninic ${ }^{5}$ \\ ${ }^{1}$ Primary Health Care Center, University of Montenegro - Faculty of Medicine, Podgorica, Montenegro \\ ${ }^{2}$ Department of Medical Biochemistry, University of Nis - School of Medicine, Nis, Serbia \\ ${ }^{3}$ Department of Health, Animal Science and Food Safety, University of Milan, Milan, Italy \\ ${ }^{4}$ Institute for Biostatistics, Medical informatics and researches in Medicine, University of Belgrade \\ - Faculty of Medicine, Belgrade, Serbia \\ ${ }^{5}$ Department of Medical Biochemistry, University of Belgrade - Faculty of Pharmacy, Belgrade, Serbia
}

\section{Summary}

Background: Nitric oxide (NO) is oxidative stress biomarker which is regarded as one of the key determinants of energy metabolism and vascular tone. Considering the controversial reports on the association between nitric oxide products (NOx) and metabolic syndrome (MetS), the aim of the current study was to examine that potential relationship. Additionally, we aimed to evaluate a broad spectrum of other oxidative stress biomarkers [i.e., malondialdehyde (MDA), advanced oxidation protein products (AOPP), xanthine oxidoreductase (XOD), xanthine oxidase (XO) xanthine dehydrogenase $(X D H)]$ in relation with MetS.

Methods: A total of 109 volunteers (46.8\% of them with MetS) were included in this cross-sectional study. Biohemical and anthropometric parameters, as well as blood pressure, were obtained. The MetS was diagnosed according to the International Diabetes Federation criteria.

Results: Multivariate logistic regression analysis showed that $X O D(O R=1.011 ; 95 \% \mathrm{Cl} 1.002-1.019 ; p=0.016)$, $X O(O R=1.014 ; 95 \% \mathrm{Cl} 1.003-1.026 ; p=0.016), M D A$ $(\mathrm{OR}=1.113 ; 95 \% \mathrm{Cl} 1.038-1.192 ; \mathrm{p}=0.003)$ and $\mathrm{AOPP}$ $(O R=1.022 ; 95 \% \mathrm{Cl} 1.005-1.039 ; \mathrm{p}=0.012)$ were the independent predictors of MetS, whereas no association between NOx and MetS was found. As XOD rose for 1 $\mathrm{U} / \mathrm{L}, \mathrm{XO}$ for $1 \mathrm{U} / \mathrm{L}, \mathrm{MDA}$ for $1 \mu \mathrm{mol} / \mathrm{L}$ and AOPP for 1 $\mathrm{T} / \mathrm{L}$, probability for MetS rose for $1.1 \%, 1.4 \%, 11.3 \%$ and

Address for correspondence:

Aleksandra Klisic, MD, PhD

Center for Laboratory Diagnostics, Primary Health Care Center Nikole Kovacevica Square 6, 81000 Podgorica, Montenegro

Phone and Fax: +38220481999

e-mail: aleksandranklisic@gmail.com

\section{Kratak sadržaj}

Uvod: Azot-monoksid (NO) je biomarker oksidativnog stresa i smatra se jednom od ključnih determinanti energetskog metabolizma i vaskularnog tonusa. S obzirom na oprečne rezultate dosadašnjih studija koje se odnose na povezanost između produkata azot-monoksida (NOx) i metaboličkog sindroma (MetS), cilj ove studije je da se ispita njihova potencijalna povezanost. Takođe, cilj je i da se ispita povezanost između širokog spektra ostalih biomarkera oksidativnog stresa [npr., malondialdehida (MDA), produkata uznapredovale oksidacije proteina (AOPP), ksantin oksidoreduktaze (XOD), ksantin oksidaze (XO) i ksantin dehidrogenaze (XDH)] i MetS.

Metode: Ukupno 109 dobrovoljaca (od kojih je 46,8\% ispunjavalo kriterijume za MetS) je uključeno u studiju preseka. Mereni su biohemijski i antropometrijski parametri, kao i krvni pritisak. Dijagnoza MetS-a je postavljena prema kriterijumima Međunarodnog udruženja za dijabetes.

Rezultati: Multivarijantna logistička regresija je pokazala da su $X O D(O R=1,011 ; 95 \% \mathrm{Cl} 1,002-1,019 ; p=0,016)$, $\mathrm{XO}(\mathrm{OR}=1,014 ; 95 \% \mathrm{Cl} 1,003-1,026 ; \mathrm{p}=0,016), \mathrm{MDA}$ $(\mathrm{OR}=1,113 ; 95 \% \mathrm{Cl} 1,038-1,192 ; \mathrm{p}=0,003)$ i AOPP $(\mathrm{OR}=1,022 ; 95 \% \mathrm{Cl}$ 1,005-1,039; $\mathrm{p}=0,012)$ nezavisni prediktori MetS-a, ali postojanje povezanosti između NOx i MetS nije utvrđeno. Sa porastom XOD za $1 \mathrm{U} / \mathrm{L}, \mathrm{XO}$ za 1 $\mathrm{U} / \mathrm{L}, \mathrm{MDA}$ za $1 \mu \mathrm{mol} / \mathrm{L}$ i AOPP za $1 \mathrm{~T} / \mathrm{L}$ verovatnoća 
$2.2 \%$, respectively. Adjusted $\mathrm{R}^{2}$ for the Model was 0.531 , which means that $53.1 \%$ of variation in MetS could be explained with this Model.

Conclusions: Unlike XOD, MDA and AOPP, NOx is not associated with MetS.

Keywords: inflammation, metabolic syndrome, obesity, oxidative stress

\section{Introduction}

Metabolic syndrome (MetS) has reached an alarming rate, parallel with increasing obesity and type 2 diabetes (DM2), thus representing one of the major public health concerns (1).

Considering the fact that abdominal obesity is the key characteristic of MetS (2), it is assumed that visceral adipose tissue through increased mitochondrial oxidation of free fatty acids represents the main generator of reactive oxygen (ROS) and reactive nitrogen species (RNS) (3). Indeed, previous studies confirmed an increase in some of the oxidative stress biomarkers, as well as a decrease in the antioxidant defence system in individuals with overweight/obesity $(4,5)$. However, it is questionable whether all of these biomarkers can predict MetS since discrepancies in the literature exist considering the relationship between oxidative stress biomarkers and MetS and/or its components (6-16).

Nitric oxide (NO) is an oxidative stress biomarker which is regarded as one of the key determinants of energy metabolism and vascular tone (12). It is generated from L-arginine, and this production is under the control of enzyme NO synthase (NOS) (12). NOS exists in three different isoforms (i.e., inducible, endothelial and neuronal) which all may have an impact on the bioavailability of $\mathrm{NO}$ in circulation $(6,12)$. However, it is believed that inducible NOS has the highest capacity for NO generation whose expression is increased in response to inflammation and oxidative stress (12).

Some studies report the decrease in serum NO $(11,12)$, while others showed its increase in metabolic disorders $(7,9)$. In addition, the relationship between serum nitric oxide products (NOx) and body fat, rather than between serum NOx and lipid parameters was found (8).

Taking into account controversial results on the association between NOx (nitrates and nitrites) and MetS, the aim of the current study was to examine that potential relationship. Additionally, we aimed to evaluate a broad spectrum of other oxidative stress biomarkers [i.e., malondialdehyde (MDA), advanced oxidation protein products (AOPP), xanthine oxidoreductase $(X O D)$, xanthine oxidase (XO) xanthine dehydrogenase $(X D H)]$ in relation with MetS. pojave MetS-a je rasla za 1,1\%, 1,4\%, 11,3\% i 2,2\%. Prilagođeni $\mathrm{R}^{2}$ za Model iznosio je 0,531 , što ukazuje na to da čak 53,1\% varijabiliteta u MetS-u može biti objašnjeno ovim modelom.

Zaključak: Za razliku od XOD, MDA i AOPP, NOx nisu povezani sa MetS-om.

Ključne reči: inflamacija, metabolički sindrom, gojaznost, oksidativni stres

\section{Materials and Methods}

\section{Study population}

A total of 109 volunteers $162.3 \%$ of them females) were recruited in the research when visiting the Primary Health Care Center in Podgorica, Montenegro, for their routine check-up in the period from October 2015 to May 2016. Clinical examinations and medical history were carried out on the same day for each participant.

The diagnosis of MetS was established according to the International Diabetes Federation criteria (17). The examinees that were eligible to enter the study were divided into two groups: a group without MetS $(n=58)$ and a group with MetS $(n=51)$.

Exclusion criteria for all potential participants were: $\mathrm{hsCRP}>10 \mathrm{mg} / \mathrm{L}$, acute inflammatory disease, diabetes mellitus, liver diseases other than steatosis, kidney diseases, malignant diseases, gout, ethanol consumption $>20 \mathrm{~g} /$ day, pregnancy, as well as unwillingness to participate in the study.

The Ethical Committee of the Primary Health Care Center in Podgorica, Montenegro approved the study protocol. All the volunteers provided signed informed consent, and the research was carried out in compliance with the Declaration of Helsinki.

\section{Anthropometric and blood pressure measurements}

Basic anthropometric measurements, as well as systolic (SBP) and diastolic blood pressure (DBP) were obtained as described elsewhere (18).

\section{Biochemical analyses}

Biochemical analyses were performed after overnight fasting of at least 8 hours. A cubital venous blood sample was collected from each participant, as previously described (18).

Lipid parameters [e.g., total cholesterol (TC), high density lipoprotein cholesterol (HDL-c), low density lipoprotein cholesterol (LDL-c), triglycerides (TG)], glucose, creatinine, uric acid, bilirubin, aspartate aminotransferase (AST), alanine aminotransferase (ALT) and gamma-glutamyl transferase (GGT), were measured using standardized enzymatic proce- 
dure (Roche Cobas 400, Mannheim, Germany). HsCRP levels were measured nephelometrically (Behring Nephelometer Analyzer, BN II, Marburg, Germany).

Serum MDA level and catalase (CAT), XOD, and $\mathrm{XO}$ activity were measured by spectrophotometric assay. Determination of MDA was based on measuring TBARS by thiobarbituric acid (TBA) test (19). Determination of $X O D$ and $X O$ in serum was based on the liberation of uric acid by using xanthine as a substrate in the presence of NADH (for XOD) or absence of NADH (for $\mathrm{XO}$ ) when only molecular oxygen was electron acceptor (20). The XDH activity was calculated by subtracting $\mathrm{XO}$ from XOD activity, and the results in $X O D, X O$ and $X D H$, respectively were expressed in U/L. Determination of serum AOPP was based on spectrophotometric detection of chloramine-T equivalents. In order to minimise the impact of storage time of samples, as well as the possible influence of TG and turbidity of samples, we modified AOPP assay by precipitating VLDL and LDL in the plasma (21).

Serum NOx was determined as follows: nitric oxide is rapidly converted to nitrite $\left(\mathrm{NO}_{2}{ }^{-}\right)$and nitrate $\left(\mathrm{NO}_{3}{ }^{-}\right)$in human serum. The measurement of these anions, commonly named as NOx, is used as an indicator of NO production. In our study, serum NOx levels were measured as previously described (22) after chemical reduction of nitrate to nitrite by $\mathrm{Cu}$-coated cadmium, followed by a colourimetric detection at 540 $\mathrm{nm}$ of nitrite as the azo dye product of the Griess reaction. The detection limit of the assay was $2.5 \mu \mathrm{mol} / \mathrm{L}$.

Catalase (CAT) test was based on the release of oxygen from hydrogen peroxide $\left(\mathrm{H}_{2} \mathrm{O}_{2}\right)$, by using the spectrophotometric assay based on the formation of its stable complex with ammonium molybdate (23).

\section{Statistical analysis}

Statistical analysis was performed with SPSS 22 Statistical Package Program for Windows (SPSS Inc, Chicago, Illinois). The parametric Student $t$-test and non-parametric Mann-Whitney $U$ test were used to test differences between two groups dependent on the variables distributions. Kolmogorov-Smirnov test was used for distribution testing. Data are shown as mean \pm standard deviation for normally distributed continuous variables, as geometrical mean (95\% confidence interval) for log-normally distributed variables (24), and median (interquartile range) for skewed distributed data. The comparisons of absolute frequencies were performed using Chi-square test for contingency tables. Logistic regression analysis was used to determine possible associations between MetS and oxidative stress and inflammation parameters. Continuous variables which were significantly different between groups and had not entered the algorithm for MetS diagnosis were classified as confounders and applied in multivariate logistic regression models in order to identify independent predictors of MetS occurrence. The Hosmer and Lemeshow test was used to examine whether there was a linear relationship between the confounders and the log odds of the dependent variable. Results are given as odds ratio (OR) with 95\% confidence intervals $(\mathrm{Cl})$. The explained variation in MetS occurrence was given by Nagelkerke $R^{2}$ value. AP $<0.05$ (two-tailed) was considered statistically significant.

\section{Results}

A summary of general demographic characteristics is listed in Table I. Significantly higher BMI and WC $(p<0.001$, for both), SBP $(p<0.001)$ and DBP

Table I Basic demographic characteristics of participants without and with metabolic syndrome.

\begin{tabular}{|l|c|c|c|}
\hline & Participants without MetS & Participants with MetS & $p$ \\
\hline $\mathrm{N}$ (male/female) & $58(20 / 38)$ & $51(21 / 30)$ & 0.602 \\
\hline Age, years* & $55(40-68)$ & $60(53-66)$ & 0.266 \\
\hline BMI, kg/m ${ }^{* *}$ & $26.21(24.99-27.50)$ & $30.47(29.40-31.59)$ & $<0.001$ \\
\hline $\mathrm{WC}, \mathrm{cm}$ & $94.78 \pm 13.42$ & $108.45 \pm 13.84$ & $<0.001$ \\
\hline $\mathrm{SBP}, \mathrm{mmHg}{ }^{*}$ & $130(136-136)$ & $141(135-148)$ & $<0.001$ \\
\hline DBP, $\mathrm{mmHg}^{*}$ & $77(70-80)$ & $80(72-90)$ & 0.010 \\
\hline Antihypertensives (No/Yes) & $28 / 21$ & $30 / 30$ & 0.582 \\
\hline Hypolipidemic drugs (No/Yes) & $48 / 10$ & $33 / 18$ & 0.053 \\
\hline Smoking habits, (Smoker/Non-smoker) & $46 / 12$ & $36 / 15$ & 0.406 \\
\hline
\end{tabular}

Data are presented as arithmetic mean \pm SD and compared by Student t-test.

* Skewed distributed data are presented as median (interquartile range) and compared by Mann-Whitney test.

** Log - normal distributed data are presented as geometric mean $(95 \% \mathrm{Cl}$ ) compared by Student t-test. Antihypertensives, hypolipidemic drugs and smoking habits are given as absolute frequencies and compared by Chi-square test for contingency tables.

BMI - Body mass index; WC - Waist circumference; SBP - Systolic blood pressure; DBP - Diastolic blood pressure 
Table II Clinical characteristics of participants without and with metabolic syndrome.

\begin{tabular}{|c|c|c|c|}
\hline & Participants without MetS & Participants with MetS & $\mathrm{p}$ \\
\hline Glucose, $\mathrm{mmol} / \mathrm{L}^{*}$ & $5.20(4.90-5.80)$ & $5.90(5.40-6.47)$ & $<0.001$ \\
\hline $\mathrm{HbA1c}, \% * *$ & $4.94(4.80-5.08)$ & $5.40(5.29-5.55)$ & $<0.001$ \\
\hline $\mathrm{TC}, \mathrm{mmol} / \mathrm{L}$ & $5.52 \pm 1.14$ & $5.74 \pm 1.33$ & 0.345 \\
\hline $\mathrm{HDL}-\mathrm{c}, \mathrm{mmol} / \mathrm{L}$ & $1.59 \pm 0.42$ & $1.34 \pm 0.36$ & $<0.001$ \\
\hline $\mathrm{LDL}-\mathrm{c}, \mathrm{mmol} / \mathrm{L}^{* *}$ & $3.18(2.95-3.43)$ & $3.39(3.07-3.74)$ & 0.303 \\
\hline $\mathrm{TG}, \mathrm{mmol} / \mathrm{L}^{* *}$ & $1.29(1.13-1.46)$ & $1.91(1.73-2.10)$ & $<0.001$ \\
\hline hsCRP, mg/L* & $1.24(0.97-1.58)$ & $2.19(1.77-2.72)$ & 0.001 \\
\hline Bilirubin, $\mu \mathrm{mol} / \mathrm{L}^{* *}$ & $7.46(6.62-8.41)$ & $7.16(6.31-8.14)$ & 0.644 \\
\hline Uric acid, $\mu \mathrm{mol} / \mathrm{L}$ & $264.07 \pm 74.77$ & $316.94 \pm 68.34$ & $<0.001$ \\
\hline Creatinine, $\mu \mathrm{mol} / \mathrm{L}^{* *}$ & $69.31(65.57-73.27)$ & $73.27(69.10-77.70)$ & 0.171 \\
\hline eGFR- ${ }_{M D R D}, \mathrm{~mL} / \mathrm{min} / 1.73 \mathrm{~m}^{2}$ & $88.22 \pm 20.90$ & $82.69 \pm 18.44$ & 0.148 \\
\hline AST, U/L* & $19(17-22)$ & $21(18-26)$ & 0.044 \\
\hline $\mathrm{ALT}, \mathrm{U} / \mathrm{L}^{*}$ & $18(14-23)$ & $25(19-35)$ & $<0.001$ \\
\hline GGT, U/L* & $13(12-18)$ & $19(14-30)$ & 0.001 \\
\hline $\mathrm{XOD}, \mathrm{U} / \mathrm{L}$ & $325.34 \pm 61.79$ & $351.60 \pm 72.77$ & 0.044 \\
\hline $\mathrm{XO}, \mathrm{U} / \mathrm{L}^{*}$ & $127.40(110.25-142.10)$ & 144.55 (122.50-175.15) & 0.012 \\
\hline $\mathrm{XDH}, \mathrm{U} / \mathrm{L}$ & $194.48 \pm 80.05$ & $199.94 \pm 83.10$ & 0.728 \\
\hline $\mathrm{MDA}, \mu \mathrm{mol} / \mathrm{L}$ & $49.74 \pm 7.28$ & $54.15 \pm 8.25$ & 0.004 \\
\hline AOPP, $T / L$ & $67.81(58.23-118.17)$ & $74.70(68.17-130.53)$ & 0.010 \\
\hline CAT, U/L & $75.06 \pm 45.19$ & $66.92 \pm 43.54$ & 0.342 \\
\hline $\mathrm{NOx}, \mu \mathrm{mol} / \mathrm{L}$ & 37.69 (32.47-54.69) & $40.02(33.36-49.69)$ & 0.913 \\
\hline
\end{tabular}

Data are presented as arithmetic mean \pm SD and compared by Student t-test.

* Skewed distributed data are presented as median (interquartile range) and compared by Mann-Whitney test.

** Log-normal distributed data are presented as geometric mean $(95 \% \mathrm{Cl}$ ) compared by Student t-test.

HbA1c-Glycated hemoglobin; TC-Total cholesterol; HDL-c-High density lipoprotein cholesterol; LDL-c-Low density lipoprotein cholesterol; TG-Triglycerides; hsCRP-High-sensitivity C-reactive protein; eGFRMDRD-Estimated glomerular filtration rate; ASTAspartate aminotransferase; ALT-Alanine aminotransferase; GGT-Gamma-glutamyl transferase; XOD-Xanthine oxidoreductase; XO-Xanthine oxidase; XDH-Xanthine dehydrogenase; MDA- Malondialdehyde; AOPP-Advanced oxidation protein products; CATCatalase; NOx-Nitric oxide products

$(p=0.010)$ were evident in the group of participants with MetS. There was no significant difference between the age of individuals in different groups. No significant unequal distributions of gender, participants with smoking habits and therapy usages were evident between tested groups.

Fasting glucose $(p<0.001), \operatorname{HbA} 1 c(p<0.001)$, TG $(p<0.001)$, uric acid concentrations $(p<0.001)$, AST, ALT and GGT activities $(p=0.044, p<0.001$ and $p=0.001$, respectively) were significantly higher in participants with MetS when compared with participants without MetS. Also, markers of oxidative stress such as XO, XOD, MDA and AOPP were evidently higher in participants with MetS $(p=0.044, p=0.012$, $p=0.004$ and $p=0.010$, respectively). There was no difference in NOx levels between participants with and without MetS $(p=0.913)$. Opposite to this, par- ticipants with MetS had a lower HDL-c concentration $(\mathrm{p}<0.001)$ (Table II).

Table III presented results of logistic regression analysis which was performed in order to examine the associations of oxidative stress and inflammation parameters (predictors) and MetS (without MetS coded 0 , with MetS coded 1) as a dependent variable. In the unadjusted model, predictors significantly associated with MetS occurrence were hsCRP $(\mathrm{OR}=1.306 ; 95 \% \mathrm{Cl} 1.052-1.621 ; \mathrm{p}=0.016), \mathrm{XOD}$ $(\mathrm{OR}=1.006 ; 95 \% \mathrm{Cl} 1.000-1.012 ; \mathrm{p}=0.047), \mathrm{XO}$ $(\mathrm{OR}=1.010 ; 95 \% \mathrm{Cl} 1.001-1.020 ; \mathrm{p}=0.025)$ and MDA $(O R=1.078 ; 95 \% \mathrm{Cl} 1.022-1.137 ; \mathrm{p}=0.006)$. As hsCRP rose for $1 \mathrm{mg} / \mathrm{L}, \mathrm{XOD}$ for $1 \mathrm{U} / \mathrm{L}, \mathrm{XO}$ for 1 $\mathrm{U} / \mathrm{L}$ and MDA for $1 \mu \mathrm{mol} / \mathrm{L}$ probability for MetS rose for $30.6 \%, 0.6 \%, 1.0 \%$ and $7.8 \%$, respectively. No significant associations were determined between 
Table III Odds ratios (OR) after univariate and multivariate logistic regression analysis for clinical parameters predicting metabolic syndrome.

\begin{tabular}{|c|c|c|c|}
\hline Predictors & $\begin{array}{l}\text { Unadjusted } \\
\text { OR (95\% Cl) }\end{array}$ & $\mathrm{p}$ & $\begin{array}{c}\text { Nagelkerke } \\
R^{2}\end{array}$ \\
\hline $\mathrm{hsCRP}, \mathrm{mg} / \mathrm{L}$ & $\begin{array}{c}1.306 \\
(1.052-1.621)\end{array}$ & 0.016 & 0.080 \\
\hline$X O D, U / L$ & $\begin{array}{c}1.006 \\
(1.000-1.012)\end{array}$ & 0.047 & 0.050 \\
\hline $\mathrm{XDH}, \mathrm{U} / \mathrm{L}$ & $\begin{array}{c}1.001 \\
(0.996-1.006)\end{array}$ & 0.725 & 0.002 \\
\hline $\mathrm{XO}, \mathrm{U} / \mathrm{L}$ & $\begin{array}{c}1.010 \\
(1.001-1.020)\end{array}$ & 0.025 & 0.068 \\
\hline $\mathrm{MDA}, \mathrm{mmol} / \mathrm{L}$ & $\begin{array}{c}1.078 \\
(1.022-1.137)\end{array}$ & 0.006 & 0.102 \\
\hline AOPP, T/L & $\begin{array}{c}1.009 \\
(0.998-1.020)\end{array}$ & 0.095 & 0.034 \\
\hline CAT, U/L & $\begin{array}{c}0.996 \\
(0.987-1.004)\end{array}$ & 0.340 & 0.011 \\
\hline $\mathrm{NOx}, \mathrm{mmol} / \mathrm{L}$ & $\begin{array}{c}1.002 \\
(0.985-1.019)\end{array}$ & 0.843 & 0 \\
\hline Model & $\begin{array}{c}\text { Adjusted } \\
\text { OR }(95 \% \mathrm{Cl})\end{array}$ & $P$ & $\begin{array}{c}\text { Nagelkerke } \\
R^{2}\end{array}$ \\
\hline hsCRP, mg/L & $\begin{array}{c}1.199 \\
(0.922-1.560)\end{array}$ & 0.175 & $\begin{array}{c}0.531 \\
\text { (for model) }\end{array}$ \\
\hline$X O D, U / L$ & $\begin{array}{c}1.011 \\
(1.002-1.019)\end{array}$ & 0.016 & \\
\hline $\mathrm{XO}, \mathrm{U} / \mathrm{L}$ & $\begin{array}{c}1.014 \\
(1.003-1.026)\end{array}$ & 0.016 & \\
\hline $\mathrm{MDA}, \mathrm{mmol} / \mathrm{L}$ & $\begin{array}{c}1.113 \\
(1.038-1.192)\end{array}$ & 0.003 & \\
\hline AOPP, T/L & $\begin{array}{c}1.022 \\
(1.005-1.039)\end{array}$ & 0.012 & \\
\hline
\end{tabular}

Model: HsCRP, uric acid, ALT, GGT, XOD, XO, MDA and AOPP

hsCRP - High-sensitivity C-reactive protein; XOD - Xanthine oxidoreductase; XO - Xanthine oxidase; XDH - Xanthine dehydrogenase; MDA - Malondialdehyde; AOPP Advanced oxidation protein products; CAT - Catalase; NOx - Nitric oxide products

XDH, AOPP, CAT, NOx and MetS (Table III). Multivariate logistic regression analysis was performed in order to test if predictors which were significant in univariate regression analysis confounded with other clinical parameters which could be independently associated with MetS occurrence. AST was not included in the logistic regression model because the Hosmer-Lemeshow test was significant $(p<0.05)$ for the Model indicating that there was no linear relation- ship between the confounders and the log odds of the dependent variable. Also, BMI, WC, SBP, DBP, lipid profile parameters, fasting glucose and $\mathrm{HbA} 1 \mathrm{c}$ were excluded from the logistic regression analysis because they were used in MetS diagnosis algorithm. Multivariate logistic regression analysis showed that $\mathrm{XOD}$ $(\mathrm{OR}=1.011 ; 95 \% \mathrm{Cl} 1.002-1.019 ; \mathrm{p}=0.016), \mathrm{XO}$ $(\mathrm{OR}=1.014 ; 95 \% \mathrm{Cl} 1.003-1.026 ; p=0.016), \mathrm{MDA}$ $(\mathrm{OR}=1.113 ; 95 \% \mathrm{Cl} 1.038-1.192 ; \mathrm{p}=0.003)$ and AOPP $(O R=1.022 ; 95 \% \mathrm{Cl} 1.005-1.039 ; p=0.012)$ were the independent predictors of MetS. As XOD rose for $1 \mathrm{U} / \mathrm{L}, \mathrm{XO}$ for $1 \mathrm{U} / \mathrm{L}, \mathrm{MDA}$ for $1 \mu \mathrm{mol} / \mathrm{L}$ and AOPP for $1 \mathrm{~T} / \mathrm{L}$, probability for MetS rose for $1.1 \%$, $1.4 \%, 11.3 \%$ and $2.2 \%$, respectively. HsCRP lost its independent prediction on MetS occurrence $(\mathrm{OR}=$ $1.199 ; 95 \% \mathrm{Cl} 0.922-1.560 ; p=0.175)$ in multivariate logistic regression analysis. Adjusted $\mathrm{R}^{2}$ for the Model was 0.531 , which means that $53.1 \%$ of the variation in MetS could be explained with this Model (Table III). Observed post-hoc power of the study based on multiple regression analysis for 8 predictors, probability level 0.05 and $R^{2}=0.531$ was 0.99 (25).

\section{Discussion}

The findings of the current study showed an independent association of different oxidative stress biomarkers with MetS (Table III). However, NOx showed no association with MetS.

In our study, we have confirmed that both, MDA and AOPP were reliable predictors of MetS in nondiabetic participants, showing that proteins are equally targeted by ROS as lipids. Furthermore, we have also shown the increase in XOD and $X O$ in individuals with MetS, and both of these biomarkers were shown to be the independent predictors of MetS (Table III).

Previous studies that examined the impact of different oxidative stress biomarkers on MetS status lack consistency (6-16). Venturini et al. (13) did not find the increase in MDA (i.e., a primary biomarker of lipid peroxidation) in individuals with obesity, but did in MetS, thus suggesting that a cluster of cardiometabolic risks, rather than obesity per se, could lead to the apparent increase in MDA level. On the other hand, Abdilla et al. (14) found no relationship between MDA and each MetS component, but only a weak association with BMI.

Regarding AOPP as a marker of oxidative damage of proteins, previous studies were consistent and showed its increase in MetS $(15,26)$. Moreover, Venturini et al. (26) reported the superiority of AOPP over lipid peroxidation biomarkers in relation to MetS components.

To our knowledge, only one study examined the $\mathrm{XO}$ activity in relation with MetS, so far. Although the latter study included a smaller sample size of examinees than ours, we have confirmed their results, thus 
showing an increase in XO activity in MetS (27). This enzyme can contribute to the controlling of vascular tone and endothelial function by modulating the bioavailability of endothelial NO. Moreover, XO is involved in adipogenesis, as well as in the production of uric acid, which all can explain the role of $X O$ in the pathogenesis of cardiometabolic diseases (28).

However, the most contradictory results were shown regarding NOx. While one group of authors reported the decrease of NOx in the state of obesity and diabetes $(11,12)$, the other claimed the opposite, showing its increase $(7,9)$ in individuals with MetS and diabetes. Our results are similar to the third group of researchers who found a non-significant increase of NOx production in obesity, diabetes and MetS $(29,30)$. Namely, Caimi et al. (30) found no difference between diabetic and non-diabetic individuals with MetS. On the other hand, Ueyama et al. (6) found the inverse correlation between NOx and HDL$c$ only in males, but not in females. However, no relationship between serum NOx levels and other MetS components, such as high BMI, high TG, or hypertension was reported (6). Furthermore, Chedraui et al. (7) also found the inverse correlation between NOx and HDL-c, but a strong positive correlation with TG in the cohort of examined postmenopausal women.

Different populations of studied groups and their different sample-size, may at least in part explain these discrepancies. Also, NOS, the enzyme responsible for NO production, exists in three isoforms, but it is suggested that inducible NOS, rather than endothelial or neuronal NOS, is the main isoform whose expression is increased in oxidant and inflam-

\section{References}

1. Saklayen MG. The Global Epidemic of the Metabolic Syndrome. Curr Hypertens Rep 2018; 20(2): 12.

2. Srikanthan K, Feyh A, Visweshwar H, Shapiro JI, Sodhi K. Systematic Review of Metabolic Syndrome Biomarkers: A Panel for Early Detection, Management, and Risk Stratification in the West Virginian Population. Int J Med Sci 2016; 13(1): 25-38.

3. Peña-Oyarzun D, Bravo-Sagua R, Diaz-Vega A, Aleman L, Chiong M, Garcia L, et al. Autophagy and oxidative stress in non-communicable diseases: A matter of the inflammatory state? Free Radic Biol Med 2018; 124: 61-78.

4. Farah R, Gilbey P, Grozovski M, Asli H, Khamisy-Farah R, Assy N. Antioxidant Enzyme Activity and Cognition in Obese Individuals with or without Metabolic Risk Factors. Exp Clin Endocrinol Diabetes 2016; 124(9): 568-71.

5. Petelin A, Tedeschi P, Maietti A, Jurdana M, Brandolini V, Pra nikar ZJ. Total Serum Antioxidant Capacity in Healthy Normal Weight and Asymptomatic Overweight Adults. Exp Clin Endocrinol Diabetes 2017; 125(7): 470-7. matory states, such as obesity (31). However, the high sensitivity of NO to ROS results in generating other reactive species, which may also influence the bioavailability of NOx (31). In addition, a problem concerning distinguishing between NO production from constitutive or inducible NOS isoforms, may also partly explain discrepancies between studies.

The cross-sectional design is the limitation of our study which does not allow us to establish the causal link between oxidative stress and MetS. However, our study has some advantages, since we have included a broad spectrum of oxidative stress biomarkers in relation with MetS. In addition, only one study, but with a smaller sample size than ours, examined the role of $\mathrm{XO}$ in MetS. Thus, new studies with longitudinal design are needed to confirm our results.

\section{Conclusion}

The finding of the current study revealed an independent relationship of different oxidative stress biomarkers with MetS occurrence. However, no association between NOx and MetS was found.

Acknowledgement. This work was financially supported in part by a grant from the Ministry of Education, Science and Technological Development, Republic of Serbia (Project number 175035).

\section{Conflict of interest statement}

The authors stated that they have no conflicts of interest regarding the publication of this article.

6. Arslan DF, Karakoyun I, Basok IB, Aksit ZM, Celik E, Dogan K, Duman C. The effects of education and training given to phlebotomists for reducing preanalytical errors. J Med Biochem 2018; 37:172-80.

7. Chedraui P, Escobar GS, Ramírez C, Pérez-López FR, Hidalgo L, Mannella $P$, et al. Nitric oxide and pro-inflammatory cytokine serum levels in postmenopausal women with the metabolic syndrome. Gynecol Endocrinol 2012; 28(10): 787-91.

8. Choi JW, Pai SH, Kim SK, Ito M, Park CS, Cha YN. Increases in nitric oxide concentrations correlate strongly with body fat in obese humans. Clin Chem 2001; 47(6): 1106-9.

9. Zahedi Asl S, Ghasemi A, Azizi F. Serum nitric oxide metabolites in subjects with metabolic syndrome. Clin Biochem 2008; 41(16-17): 1342-7.

10. Yubero-Serrano EM, Delgado-Lista J, Peña-Orihuela $P$, Perez-Martinez P, Fuentes F, Marin C, et al. Oxidative stress is associated with the number of components of 
metabolic syndrome: LIPGENE study. Exp Mol Med 2013; 45: e28.

11. Grandl G, Wolfrum C. Hemostasis, endothelial stress, inflammation, and the metabolic syndrome. Semin Immunopathol 2018; 40(2): 215-24.

12. Sansbury BE, Hill BG. Regulation of obesity and insulin resistance by nitric oxide. Free Radic Biol Med 2014; 73: 383-99.

13. Venturini D, Simão AN, Scripes NA, Bahls LD, Melo PA, Belinetti FM, et al. Evaluation of oxidative stress in overweight subjects with or without metabolic syndrome. Obesity (Silver Spring) 2012; 20(12): 2361-6.

14. Abdilla N, Tormo MC, Fabia MJ, Chaves FJ, Saez G, Redon J. Impact of the components of metabolic syndrome on oxidative stress and enzymatic antioxidant activity in essential hypertension. J Hum Hypertens 2007; 21(1): 68-75.

15. Zurawska-Płaksej E, Grzebyk E, Marciniak D, Szyma skaChabowska A, Piwowar A. Oxidatively modified forms of albumin in patients with risk factors of metabolic syndrome. J Endocrinol Invest 2014; 37(9): 819-27.

16. Browning LM, Jebb SA, Mishra GD, Cooke JH, O'Connell MA, Crook MA, Krebs JD. Elevated sialic acid, but not CRP, predicts features of the metabolic syndrome independently of $\mathrm{BMI}$ in women. Int J Obes Relat Metab Disord 2004; 28(8): 1004-10.

17. International Diabetes Federation-IDF. The IDF consensus worldwide definition of the Metabolic Syndrome. Brussels: IDF, 2005. https://www.idf.org/e-library/consensus-statements/60-idfconsensusworldwide-definitionof-the-metabolic-syndrome.html

18. Klisic A, Kotur-Stevuljevic J, Kavaric N, Martinovic M, Matic $M$. The association between follicle stimulating hormone and glutathione peroxidase activity is dependent on abdominal obesity in postmenopausal women. Eat Weight Disord - St 2018; 23(1): 133-41.

19. Andreeva LI, Kozhemiakin LA, Kishkun AA. Modification of the method of determining lipid peroxidation in a test using thiobarbituric acid. Lab Delo 1988; (11): 41-3.

20. Kizaki H, Sakurada T. Simple micro-assay methods for enzymes of purine metabolism. J Lab Clin Med 1977; 89(5): 1135-44.
21. Witko-Sarsat V, Gausson V, Descamps-Latscha B. Are advanced oxidation protein products potential uremic toxins? Kidney Int Suppl 2003; (84): S11-14.

22. Navarro-Gonzales JA, Garcia-Benayas C, Arenos J. Semiautomated measurement of nitrate in biological fluids. Clin Chem 1998; 44: 679-81.

23. Góth L. A simple method for determination of serum catalase activity and revision of reference range. Clin Chim Acta 1991; 196 (2-3): 143-51.

24. Bland JM, Altman DG. Transformations, means and confidence intervals. BMJ 1996; 312: 1079.

25. Milinković N, Ignjatović S, Šumarac Z, Majkić-Singh N. Uncertainty of measurement in laboratory medicine. J Med Biochem 2018; 37: 279-88.

26. Venturini D, Simão AN, Dichi I. Advanced oxidation protein products are more related to metabolic syndrome components than biomarkers of lipid peroxidation. Nutr Res 2015;3 5(9): 759-65.

27. Feoli AM, Macagnan FE, Piovesan CH, Bodanese LC, Siqueira IR. Xanthine oxidase activity is associated with risk factors for cardiovascular disease and inflammatory and oxidative status markers in metabolic syndrome: effects of a single exercise session. Oxid Med Cell Longev 2014; 2014: 587083

28. Battelli MG, Bortolotti M, Polito L, Bolognesi A. The role of xanthine oxidoreductase and uric acid in metabolic syndrome. Biochim Biophys Acta 2018; 1864(8) : 2557-65.

29. Ferlito S, Gallina M. Nitrite plasma levels in type 1 and 2 diabetics with and without complications. Minerva Endocrinol 1999; 24: 117-21.

30. Caimi G, Lo Presti R, Montana M, Noto D, Canino B, Averna MR, Hopps E. Lipid peroxidation, nitric oxide metabolites, and their ratio in a group of subjects with metabolic syndrome. Oxid Med Cell Longev 2014; 2014: 824756.

31. Correia-Costa L, Sousa T, Morato M, Cosme D, Afonso J, Areias JC, et al. Oxidative stress and nitric oxide are increased in obese children and correlate with cardiometabolic risk and renal function. Br J Nutr 2016; 116(5): 805-15. 